\title{
Pengaruh Pemberian Kompos Padat dan Kompos Cair Terhadap Pertumbuhan Tanaman yang Ditumbuhkan pada Media Tanah atau Gambut
}

\section{The effect of Solid and Liquid Compost Amandment on The Growth of Plant Grown in Soil or Peat Substrate}

\author{
Wahyu Harso \\ Jurusan Biologi Fakultas MIPA Universitas Tadulako
}

\begin{abstract}
Application of compost can be used to replace fertilizer utilization due to negative impacts of fertilizer on soil fertility. However, the effects of compost on the plant growth depend on the quality and type of compost. The aim of this study was to observe the effects of compost amendment with different type of compost (solid and liquid compost) to soil or peat as growth medium on plant growth. Tagetes patula was grown either in soil or peat substrate. These substrates were supplied with either solid or liquid compost. These treatment combinations were repeated 4 times. The result showed that application of solid compost was more increasing on plant growth than application of liquid compost when plant was grown in soil substrate. On the contrary, application of liquid compost was more increasing on plant growth than apllication of solid compost when plant was grown in peat substrate. Type of compost and growth medium must be considered before their application. Solid rather than liquid compost give more benefit to plant growth when the growth medium has high bulk density and conversely, liquid compost give more beneft to plant growth when the growth medium has low bulk density.
\end{abstract}

Key words: Solid compost, Liquid compost, Soil, Peat, Tagetes patula.

\begin{abstract}
ABSTRAK
Kompos dapat digunakan untuk menggantikan penggunaan pupuk kimia yang memiliki pengaruh negatif terhadap kesuburan tanah. Namun demikian pengaruh kompos pada pertumbuhan tanaman tergantung pada kualitas dan tipe kompos. Penelitian ini bertujuan untuk megukur pengaruh pemberian kompos dengan tipe yang berbeda (kompos padat dan kompos cair) pada media tanam berupa tanah dan gambut terhadap pertumbuhan tanaman. Penelitian ini menggunakan Tagetes patula yang ditumbuhkan di tanah atau di gambut yang diberi kompos padat atau cair. Kombinasi perlakuan ini diulang sebanyak 4 kali. Hasil penelitian menunjukkan bahwa pemberian kompos padat akan lebih meningkatkan pertumbuhan tanaman ketika ditumbuhkan di tanah dibandingkan dengan pemberian kompos cair. Sebaliknya pemberian kompos cair akan lebih meningkatkan pertumbuhan tanaman ketika tanaman ditumbuhkan di gambut dibandingkan pemberian kompos padat. Tipe kompos harus diperhatikan sebelum digunakan. Penggunaan kompos harus memperhatikan
\end{abstract}


sifat fisik dari media tanam. Media tanam yang memilki kepadatan tanah yang tinggi lebih baik menggunakan kompos padat, sementara media tanam yang memilki kepadatan rendah lebih baik menggunakan kompos cair.

\section{Kata kunci: Kompos padat, Kompos cair, Tanah, Gambut, Tagetes patula}

\section{LATAR BELAKANG}

Kompos adalah proses dekomposisi dan daur ulang bahan organik yang terkontrol untuk menghasilkan humus. Bahan organik untuk menghasilkan kompos dapat berupa kotoran hewan, potongan tumbuhan, atau sisa-sisa makanan (Risse and Faucette, 2001). Aplikasi kompos pada tanah dapat meningkatkan pertumbuhan tanaman karena kompos dapat memperbaiki a. Sifat fisik tanah yaitu memperbaiki struktur, porositas, densitas tanah dan meningkatkan kemampuan tanah untuk menahan air, b. Sifat kimia tanah yaitu menyediakan berbagai macam unsur makro dan mikro, memperbaiki kapasitas tukar kation tanah, memperbaiki dan menstabilkan pH tanah, c. Sifat biologi tanah seperti mengontrol atau menekan mikrooganisme pathogen tanah dan menyediakan mikroorganisme yang dapat memobilisasi unsur hara di dalam tanah (The US Composting Council, 2001). Hal ini disebabkan karena kompos mengandung bahan organik yang tinggi (Sarwar et al., 2008) dan kaya akan mikrooganisme (Mehta et al., 2011).

Kompos cair adalah salah satu teknik alternatif ekstraksi dari bahan kompos dengan merendam kompos di dalam air dengan menggunakan berbagai metode pengolahan. Kompos cair terdiri dari dua macam, yaitu kompos cair diaerasi dan kompos cair tak diaerasi. Aplikasi kompos cair merupakan salah satu pilihan untuk meningkatkan kesuburan tanaman dengan menambahkan mikrooganisme yang dapat memobilisasi unsur hara di dalam tanah dan menambahkan unsur hara terlarut ke dalam tanah (Kim et al., 2015). Aplikasi kompos dapat menggantikan pupuk kimia sintetis (Baldi et al., 2010) dimana pupuk kimia sintetis memiliki pengaruh negatif terhadap kesuburan tanah. Penggunaan pupuk nitrogen sintetis akan mengurangi kandungan humus dan biodiverisitas di dalam tanah, selain itu pupuk nitrogen akan menurunkan $\mathrm{pH}$ tanah sehingga mengurangi ketersediaan fosfor bagi tanaman (Kotschi, 2015). Namun demikian penggunaan kompos dalam meningkatkan tanaman tergantung dari kualitas bahan kompos (Cozzolino et al., 2016) dan tipe kompos (padat atau cair) (Shourije et al., 2014).

Di lain pihak, produksi tanaman berbasis penggunaan tanah menghadapi tantangan besar seiring meningkatnya peningkatan jumlah penduduk di seluruh 
dunia yang diikuti oleh urbanisasi dan industrialisasi sehingga menurunkan ketersediaan tanah bagi peningkatan produksi tanaman. Sehingga media tumbuh tanpa tanah menjadi relevan untuk menghadapi tantangan ini (Hussain et al., 2014). Cara untuk menumbuhkan tanaman tanpa tanah sebagai media tumbuh dapat dibagi menjadi dua katagori, pertama adalah biakan cair (hidroponik) dimana larutan hara diedarkan kembali setelah diaerasi dan $\mathrm{pH}$ dan tingkat unsur hara disesuaikan dan yang kedua adalah biakan agregat (padat) dimana unsur hara disuplai ke tanaman melalui sistim irigasi ke dalam media tanam yang dapat berupa bahan serbuk gergaji, kulit kayu, kepingan kayu, sabut kelapa, dan gambut (Olympios, 1999). Pada penelitian ini digunakan gambut sebagai media tanam selain tanah karena gambut masih tersedia dalam jumlah besar dan memiliki sifat yang menguntungkan dengan memiliki kemampuan mengikat air yang besar, homogenitas dan ketersediaan produk yang terjaga, tiadanya bibit gulma dan pathogen tanah, kepadatan yang rendah, serta $\mathrm{pH}$ dan kandungan hara yang rendah sehingga memudahkan untuk mengatur kebutuhan hara dan $\mathrm{pH}$ yang dibutuhkan oleh tumbuhan tertentu (Steinner and Harttung, 2014).

Tagetes patula L. digunakan pada penelitian ini karena tanaman ini sering dibudidayakan sebagai tanaman hias. Bunga dari tanaman ini dapat digunakan untuk mewarnai atau memberi rasa pada makanan selain itu juga bunga ini mengandung karotenoid, flavonoid, dan monoterpenoid yang dapat memiliki potensi untuk digunakan sebagai bahan obat (Yasukawa and Yoshimasa, 2013).

Penelitian ini bertujuan untuk mengetahui apakah tipe kompos yang berupa kompos padat dan kompos cair mempunyai pengaruh yang sama dalam meningkatkan pertumbuhan dari tanaman $T$. patula yang ditumbuhkan di tanah dan di gambut dimana tanah sebagai media tanam memiliki porositas dan bahan organik yang lebih rendah dibandingkan dengan gambut.

\section{BAHAN DAN METODE}

Penelitian dilakukan dengan menggunakan rancangan acak lengkap dengan dua faktorial. Faktor pertama adalah tipe kompos (K) yaitu kompos padat $(\mathrm{P})$ dan kompos cair (C), dan faktor kedua adalah jenis media tumbuh (M) yaitu tanah (T) dan gambut (G). Masing-masing kombinasi perlakuan dilakukan pengulangan sebanyak empat kali.

Biji Tagetes patula L. yang telah diseleksi kemudian disterilisasi dengan natrium hipoklorit (50 $\mathrm{ml}$ per liter) selama 30 menit dan dikecambahkan pada kertas saring yang dibasahi dengan larutan 2.28 $\mathrm{mM} \mathrm{CaSO}$. Kecambah ditumbuhkan di 
dalam gelas kimia yang ditutup dengan kertas alumunium dan diberi akuades jika dibutuhkan untuk menghindari dari keringnya kertas saring. Setelah semai berumur tujuh hari, semai yang terpilih dipindahkan ke dalam pot plastik yang berukuran $700 \mathrm{ml}$ dan berisi 636 gram tanah steril dengan kepadatan $1.3 \mathrm{gr} \mathrm{cm}^{-3}$ atau berisi 240 gram gambut dengan kepadatan $0.49 \mathrm{~g} \mathrm{~cm}^{-3}$. Tanah yang digunakan adalah tanah jenis lempung berpasir (45,5\% pasir, $42,0 \%$ debu dan 12,8\% lempung). Tanah memiliki $\mathrm{pH}\left(\mathrm{CaCl}_{2}\right) 7.3$ dan kandungan bahan organik $12.8 \%$ sebelum disterilisasi (Neumann and George, 2005). Tanah sebelum digunakan disterilisasi dalam oven selama 48 jam pada suhu $85^{\circ} \mathrm{C}$. Gambut yang digunakan adalah campuran dari lumut yang terdekomposisi tidak sempurna, lempung dan zat tambahan lain dengan $\mathrm{pH}$ $\left(\mathrm{CaCl}_{2}\right) 5.8$ dan kandungan bahan organik 75\%. Masing-masing pot diberi kompos segar sebanyak 92.7 gram secara homogen atau $35 \mathrm{ml}$ kompos cair. Setiap mililiter kompos cair mengandung $8.9 \mathrm{mM} \mathrm{P}$. Kompos cair dibuat dengan cara mencampurkan $500 \mathrm{ml}$ kompos, $2000 \mathrm{ml}$ akuabides dan gula kemudian diaerasi selama dua hari, kemudian disaring dengan menggunakan ayakan yang berukuran 50 $\mu \mathrm{m}$.

Kompos yang digunakan adalah kompos komersial dari Lumbrico Wumfarm
Jerman yang mengandung $7.3 \mathrm{mg} \mathrm{Al}, 5136$ $\mathrm{mg} \mathrm{Ca}, 6.5 \mathrm{mg} \mathrm{Fe}, 1784 \mathrm{mg} \mathrm{K}, 1214 \mathrm{mg}$ Mg, $5.8 \mathrm{mg}$ Mn, $281 \mathrm{mg} \mathrm{Na}, 819 \mathrm{mg}$ P, 84.5 $\mathrm{mg} \mathrm{S}$, $1.8 \mathrm{mg} \mathrm{Zn}$ per $\mathrm{kg}$ berat kering kompos. Kompos memiliki $\mathrm{pH}\left(\mathrm{CaCl}_{2}\right) 6.45$, Konsentrasi C $14.7 \%$ dan N $0.885 \%$ dengan rasio $\mathrm{C} / \mathrm{N}$ : 17 berdasarkan informasi yang diperoleh dari label pada kemasan kompos.

Pot diletakkan secara acak lengkap di dalam greenhouse di Grossbeeren Jerman selama sembilan minggu dengan rata-rata intensitas harian sebesar $709 \mu$ mol per meter persegi perdetik dengan panjang siang hari selama 16 jam. Suhu rata-rata selama penelitian adalah $27^{\circ} \mathrm{C}$ pada siang hari dan $21^{\circ} \mathrm{C}$ pada malam hari dengan kelembaban sekitar 55\%. Data yang diperoleh berupa berat kering keseluruhan tanaman, berat kering tajuk, berat kering akar, nisbah akar/tajuk, jumlah bunga yang terbentuk, jumlah bunga yang mekar, serta kandungan $\mathrm{P}$ dan $\mathrm{N}$ tanaman dianalisis dengan menggunakan Two-way ANOVA dan diuji lanjut dengan DMRT dan dinyatakan berbeda nyata ketika $\mathrm{P}<0.05$.

\section{HASIL DAN PEMBAHASAN}

Berdasarkan hasil perhitungan statistik (Tabel 1) dinyatakan bahwa jenis media tanam akan mempengaruhi seluruh paramenter yang diamati. Tanaman $T$. patula yang ditumbuhkan pada media tanam berupa gambut terutama yang dipupuk dengan pupuk kompos cair memiliki 
pertumbuhan yang lebih besar bila tanam memiliki berat kering yang lebih dibandingkan dengan tanaman $T$. patula besar dibandingkan dengan berat kering yang ditanam pada media tanah yang dipupuk dengan jenis kompos yang sama. Hal ini bisa disebabkan karena gambut sebagai media tumbuh memiliki porositas yang lebih tinggi dan kepadatan yang lebih rendah dibanding dengan tanah (Rezanezhad et al., 2016) sehingga lebih menguntungkan untuk pertumbuhan akar. Ini juga didukung oleh data pengamatan (Tabel 1) bahwa berat akar dari $T$. patula yang ditumbuhkan di tanah sebagai media tanam. Meningkatnya pertumbuhan akar akan memperbesar penyerapan unsur hara $\mathrm{P}$ dan $\mathrm{N}$ sehingga meningkatkan pertumbuhan tanaman. akan memperbanyak jumlah bunga yang terbentuk dan jumlah bunga yang mekar (Mantovani and Iglesias, 2009). Pada penelitian ini kandungan $\mathrm{P}$ dan $\mathrm{N}$

kering akar pada $T$. patula yang ditumbuhkan pada gambut sebagai media

Tabel 1. Hasil pengamatan berat kering total, berat kering tajuk, berat kering akar, nisbah tajuk/akar, jumlah bunga dan bunga mekar, kandungan $\mathrm{P}$ dan $\mathrm{N}$ tumbuhan setelah tanaman berumur 9 minggu.

\begin{tabular}{|c|c|c|c|c|c|c|c|}
\hline \multirow{3}{*}{ Pengamatan } & \multicolumn{4}{|c|}{ Perlakuan } & & & \\
\hline & \multicolumn{2}{|c|}{$\mathrm{T}$} & \multicolumn{2}{|c|}{$\mathrm{G}$} & \multicolumn{3}{|c|}{ Hasil analisis } \\
\hline & $\mathrm{P}$ & $\mathrm{C}$ & $\mathrm{P}$ & $\mathrm{C}$ & $\mathrm{M}$ & $\mathrm{K}$ & $\mathrm{I}$ \\
\hline $\begin{array}{l}\text { Berat kering } \\
\text { total }(\mathrm{gr})\end{array}$ & $6.14 \pm 0.50 b$ & $0.49 \pm 0.42 a$ & $6.40 \pm 0.62 b$ & $8.58 \pm 0.36 c$ & $*$ & $*$ & $*$ \\
\hline $\begin{array}{l}\text { Berat kering } \\
\text { tajuk (gr) }\end{array}$ & $5.06 \pm 0.33 b$ & $0.40 \pm 0.32 \mathrm{a}$ & $4.91 \pm 0.47 b$ & $6.76 \pm 0.05 c$ & $*$ & $*$ & $*$ \\
\hline $\begin{array}{l}\text { Berat kering } \\
\text { akar }(\mathrm{gr})\end{array}$ & $0.98 \pm 0.20 \mathrm{~b}$ & $0.04 \pm 0.05 a$ & $1.40 \pm 0.22 \mathrm{c}$ & $1.76 \pm 0.38 c$ & $*$ & $*$ & $*$ \\
\hline $\begin{array}{l}\text { Nisbah } \\
\text { tajuk/akar }\end{array}$ & $4.78 \pm 0.78 \mathrm{ab}$ & $5.73 \pm 1.43 b$ & $3.30 \pm 0.31 \mathrm{a}$ & $3.80 \pm 0.75 a$ & $*$ & tb & tb \\
\hline Jumlah bunga & $4.00 \pm 2.16 \mathrm{a}$ & $1.75 \pm 0.69 a$ & $5.25 \pm 2.87 \mathrm{a}$ & $11.33 \pm 5.51 b$ & $*$ & tb & $*$ \\
\hline $\begin{array}{l}\text { Jumlah bunga } \\
\text { mekar }\end{array}$ & $1.00 \pm 0.00 \mathrm{ab}$ & $0.25 \pm 0.50 \mathrm{a}$ & $1.50 \pm 0.58 b$ & $1.67 \pm 0.58 b$ & $*$ & tb & tb \\
\hline $\begin{array}{l}\text { Kandungan P } \\
\text { (mg/tumbuhan) }\end{array}$ & $9.42 \pm 0.53 a$ & - & $11.86 \pm 0.65 b$ & $12.43 \pm 0.29 b$ & $*$ & tb & - \\
\hline $\begin{array}{l}\text { Kandungan } \mathrm{N} \\
\text { (mg/tumbuhan) }\end{array}$ & $56.05 \pm 2.44 b$ & - & $50.15 \pm 0.91 a$ & $93.65 \pm 5.55 c$ & $*$ & $*$ & - \\
\hline
\end{tabular}

Keterangan: Data yang ditampilkan adalah data rata-rata \pm standar deviasi. Rata-rata yang diikuti oleh huruf yang sama pada baris yang sama tidak menunjukkan beda nyata $(\mathrm{P}<0.05)$. Perlakuan terdiri dari dua faktor yaitu faktor pertama adalah media tumbuh $(\mathrm{M})$ yang terdiri dari tanah $(\mathrm{T})$ dan gambut $(\mathrm{G})$ dan faktor kedua adalah tipe kompos $(\mathrm{K})$ yang terdiri dari kompos padat $(\mathrm{P})$ dan kompos cair $(\mathrm{C})$. Hasil analisis ditunjukan dengan * adalah berbeda nyata dan tb adalah tidak berbeda nyata.

pada T. patula yang ditumbuhkan di tanah kering dari tanaman tersebut tidak cukup sebagai media tanam yang diberi kompos untuk dilakukan analisis kandungan $\mathrm{P}$ dan $\mathrm{N}$ cair tidak diukur, hal ini disebabkan berat nya. 
Pemberian kompos padat di tanah sebagai media tanam lebih menguntungkan pertumbuhan $T$. patula dibandingkan dengan pemberian kompos cair. Kompos padat dapat meningkatkan sifat fisik tanah seperti meningkatkan porositas tanah, meningkatkan kemampuan tanah mengikat air dan menurunkan kepadatan tanah sehingga menguntungkan untuk pertumbuhan akar yang selanjutnya akan meningkatkan pertumbuhan tanaman. Sebaliknya, pemberian kompos padat tidak menghasilkan berat kering lebih besar dibandingkan dengan kompos cair dari pada T. patula yang ditumbuhkan di gambut sebagai media tanam. Hal ini mungkin disebabkan oleh ukuran penyusun kompos padat yang lebih halus dibandingkan dengan ukuran penyusun gambut, sehinga porositas media tanam menjadi lebih rendah dibandingkan sebelum diberikan kompos padat, sementara itu kompos cair tidak memiliki partikel bahan organik sehingga tidak berpengaruh terhadap sifat fisik dari gambut sebagai media tanam.

\section{KESIMPULAN}

Pemberian kompos padat akan meningkatkan pertumbuhan tanaman bila media tanam yang ditambahkan memiliki sifat fisik tanah yang kurang baik seperti tingkat kepadatan tanah yang tinggi dan cenderung akan mengurangi pertumbuhan tanaman bila diberikan pada media tanam yang memiliki sifat fisik yang baik atau ukuran penyusun media tanam lebih besar dibandingkan dengan ukuran penyusun kompos. Oleh karena itu sebelum menggunakan kompos padat atau cair harus benar-benar diperhatikan sifat fisik dari media tanam yang akan digunakan.

\section{DAFTAR PUSTAKA}

Baldi, E., Toselli, M., Marcolini, G., Quartieri, Cirillo, E., Innocenti, A., and Marangoni, B. 2010. Compost can successfully replace mineral fertilizers in the nutrient management of commercial peach orchard. Soil Use and Management, 26(3): 346-353.

Cozzolino, V., Meo, V. D.,Sapccini, R., and Piccolo, A. 2016. The molecular characteristics of compost affect plant growth, arbuscular mycorrhizal fungi, and soil microbial community composition. Biology and Fertility of Soils, 52(1): 15-29.

Hussain, A., Iqbal, K., Aziem, S., Mahato, P., and Negi, A. K. 2014. A review on the science of growing crops without soil (soilless culture) - A novel alternative for growing crops. International Journal of Agriculture and Crop Sciences, 7(11): 833-842.

Kim, M. J., Shim, C. K., Kim, Y. K., Hong, S. J., Park, J. H., Han, E. J., Kim, J. H., and Kim, S. C. 2015. Effect of aerated compost tea on the growth promotion of lettuce, soybean and sweet potato in organic cultivation. Plant Pathology Journal 31(3): 259268.

Kotschi, J. 2015. A soiled reputation: Adverse impacts of mineral fertilizers in tropical agriculture. Heinrich Böll Stiftung, WWF Germany. Retrieved from WWF website: https://www.wwf.de/fileadmin/fmwwf/Publikationen-PDF/WWF- 
Study_Adverse_impacts_of_mineral_f ertilizers_in_tropical_agriculture.pdf.

Mantovani, A., and Iglesias, R.R. 2009. Size-dependent allocation of biomass to ancillary versus flowers of the inflorescences of the epiphyte Tillandsia stricta Soland (Bromeliaceae). Acta Botanica Brasilica, 23(1): 130-135.

Mehta, C. M., Gupta, V., Singh, S., Srivastava, R., Sen, E., Romantschuk, M., and Sharma, A. K. 2012. Role of microbiologically rich compost in reducing biotic and abiotic stresses. In. Satyanarayana, T., Johri, B. N., and Prakash, A. (Eds.). Microorganisms in environmental management: microbes and environment (pp. 131-134). Dodrecht: Springer.

Neumann, E. and George, E. 2005. Extraction of extraradical arbuscular mycorrhizal mycelium from compartment filled with soil and glass beads. Mycorrhiza, 15(7): 533-537.

Olympios, C. M. 1999. Overview of soilless culture: Advantafe, constraints and perspectives for its use in Mediterranean countries. Cahier Option Méditerranéenes, 31: 307-324.

Rezanezhad, F., Price, J. S., Quinton, W. L., Lennartz, B., Milojevic, T., and Cappellen, P. V. 2016. Structure of peat soils and implications for water storage, flow and solute transport: A review update for geochemists. Chemical Geology, 429: 75-84.

Risse, M., and Faucette, B. 2001. Compost utilization for erosion control. University of Georgia Extension Bulletin number 1200. http://extension.uga.edu/publications/f iles/pdf/B\%201200_5.PDF

Sarwar, G., Schemeisky, H., Hussain, N., Muhannad, S., Ibrahim, M., and Safdar, E. 2008. Improvement of soil physical and chemical properties with compost application in rice-wheat cropping system. Pakistan Journal of Botany, 40(1): 275-282.
Shourije, F. A., Sadeghi, H., and Pesarakli, M. 2014. Effects of different types of composts on soil characteristics and morphological traits of two dry rangeland species. Journal of Plant Nutrition, 37(12): 1965-1680.

Steiner, C., and Harttung, T. 2014. Biochar as growing media additive and peat substitute. Solid Earth, 5: 995-999.

The US Composting Council, 2001. Field guide to compost use.. Retrieved from The US Composting Council website: http://compostingcouncil.org/wp/wpcontent/plugins/wppdfupload/pdf/1330 /Field_Guide_to_Compost_Use.pdf

Yasukawa, K., and Kasahara, Y. 2013. Effects of flavonoids from French Marigold (floret of Tagetes patula L.) on acute inflammation model. International Journal of Inflammation, 2013: 1-5. 